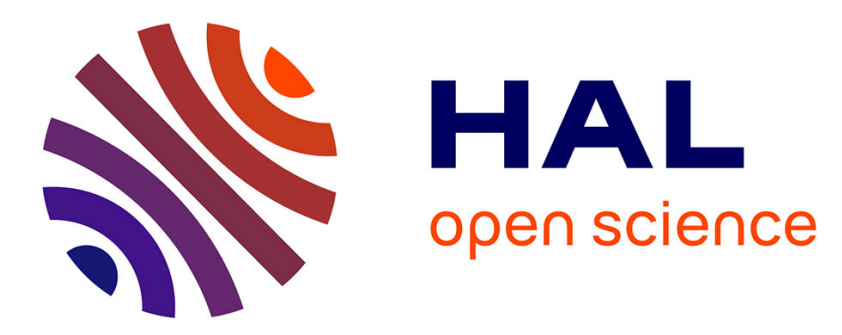

\title{
Chemical diversity and antimicrobial activity of the essential oils of four Apiaceae species growing wild in Lebanon
}

Madona Khoury, Marc El Beyrouthy, Véronique Eparvier, Naim N. Ouaini, Didier Stien

\section{To cite this version:}

Madona Khoury, Marc El Beyrouthy, Véronique Eparvier, Naim N. Ouaini, Didier Stien. Chemical diversity and antimicrobial activity of the essential oils of four Apiaceae species growing wild in Lebanon. Journal of Essential Oil Research, 2018, 30 (1), pp.25-31. 10.1080/10412905.2017.1372314 . hal-02349254

\section{HAL Id: hal-02349254 \\ https://hal.science/hal-02349254}

Submitted on 5 Nov 2019

HAL is a multi-disciplinary open access archive for the deposit and dissemination of scientific research documents, whether they are published or not. The documents may come from teaching and research institutions in France or abroad, or from public or private research centers.
L'archive ouverte pluridisciplinaire HAL, est destinée au dépôt et à la diffusion de documents scientifiques de niveau recherche, publiés ou non, émanant des établissements d'enseignement et de recherche français ou étrangers, des laboratoires publics ou privés. 


\section{Chemical diversity and antimicrobial activity of the essential oils of four Apiaceae species growing wild in Lebanon}

Madona Khoury ${ }^{\mathrm{a}, \mathrm{b}}$, Marc El Beyrouthy ${ }^{\mathrm{b}}$, Véronique Eparvier ${ }^{\mathrm{a}}$, Naïm Ouaini ${ }^{\mathrm{b}}$, Didier Stien ${ }^{\mathrm{a}, \mathrm{c}}$

${ }^{a}$ CNRS, Institut de Chimie des Substances Naturelles, UPR 2301, 1 Avenue de la Terrasse, 91198 Gif-sur-Yvette, France

${ }^{b}$ Department of Agricultural Sciences, Holy Spirit University of Kaslik, Kaslik, B.P. 446, Jounieh, Lebanon

${ }^{c}$ Sorbonne Universités, UPMC Univ Paris 06, CNRS, Laboratoire de Biodiversité et Biotechnologies Microbiennes (LBBM), Observatoire Océanologique, 66650 Banyuls-surmer, France

* Corresponding author: phone: +9619600878; E-mail: marcelbeyrouthy@ usek.edu.lb 


\section{Chemical diversity and antimicrobial activity of the essential oils of four Apiaceae species growing wild in Lebanon}

The Apiaceae species are largely used in folk medicine to treat many diseases, including microbial infections. The essential oils (EOs) of Prangos asperula Boiss., Daucus carota L. subsp. maximus, Ferula elaeochytris Korovin and Smyrnium olusatrum L. were analysed by GC, GC-MS and NMR. The major components were as follows: sabinene $(29.8 \%)$ and $\beta$ phellandrene (19.2\%) were found in the P. asperula fruit oil; $\alpha$-pinene (27.4\%) and carotol (26.3\%) were found in the $D$. carota flower oil; $\alpha$-pinene (71.8\%) was the major compound in the F. elaeochytris fruit oil; and the S. olusatrum flowerings tops EO was mainly composed of furanodiene (44.6\%) and furanoeremophil-1-one (28.5\%). D. carota and S. olusatrum were the most active oils especially against Staphylococcus aureus and the dermatophytes; the MIC values ranged from 8 to $64 \mu \mathrm{g} / \mathrm{ml}$. Some of these EOs constituents hold promising antimicrobial potentials, confirming the traditional medical use of the plants.

Keywords: antimicrobials; essential oils; Prangos asperula; Daucus carota; Smyrnium olusatrum; Ferula elaeochytris. 


\section{Introduction:}

In recent decades, the incidence of microbial infections in humans, particularly those involving the skin and mucosal surfaces, has increased considerably. A concomitant and dramatic increase of cases of immunocompromised patients which frequently develop opportunistic and superficial microbial infections has also been reported recently (1). In addition, the abuse or misuse of antibiotic and antimycotic drugs has led to appearance of multiresistant strains. Therefore, microbial diseases have emerged as an important public health problem associated with an increased rate of mortality and morbidity, as well as a rising economic burden $(2,3)$. Therefore, the development of new and effective antimicrobial compounds is urgent. In this matter, natural substances, particularly essential oils, have attracted a great deal of interest (4). In fact, essential oils may offer an alternative source of antimicrobial agents because they contain a wide range of bioactive chemicals with both specific and general antimicrobial potential $(5,6)$. They can be viewed as examples of evolution-optimized mixtures of natural products that can inspire the discovery of bio-inspired synthetic synergistic systems.

South-West Asia is a region with high Apiaceae diversity. This family is well represented in Lebanon with at least 56 genera and 120 species (7). Species in the Apiaceae family are very important in the pharmacopeia of the Middle East and the rest of the world (8).

For this study, the relationship between the antimicrobial potential and the chemical composition of four wild Apiaceae species essential oils used in the Lebanese traditional medicine $(9,10,11)$ was investigated. The tested oils were those from Ferula elaeochytris Korovin (endemic to Lebanon, Syria and eastern Mediterranean Turkey) (12, 13), Prangos asperula Boiss. (endemic to Lebanon, Syria, Jordan and Palestine) (12, 14), Smyrnium 
olusatrum L. (known as Alexanders or wild celery) and Daucus carota L. subsp. maximus (Desf.) Ball. (common names wild carrot, bird's nest, bishop's lace and Queen Anne's lace). To the best of our knowledge, little information is known about the phytochemical composition and antimicrobial activity of Ferula elaeochytris and Prangos asperula EOs. Therefore, it was interesting to put into perspective those two oils in terms of composition and biological activity, as well as, the EO of other species widespread in Lebanon and belonging to the same family.

\section{Experimental:}

\subsection{Plant material:}

Specimens of the four Apiaceae species were collected as follows:

- Flowers from Daucus carota were collected from a natural stand from the region of Adonis, Keserwan ( $\left.33^{\circ} 58^{\prime} 05.91^{\prime \prime} \mathrm{N} 35^{\circ} 36^{\prime} 35.20^{\prime \prime} \mathrm{E}\right)$ at an altitude of approximately $50 \mathrm{~m}$ in May 2012.

- Fruits from Ferula elaeochytris were collected from a natural stand in Faraya, Mount Lebanon (3400'33.21" N 3550'02.50" E), at approximately 1500 m altitude, in July 2012.

- Fruits from Prangos asperula were collected from a natural stand in Laqlouq, Mount Lebanon (3407'54.47" N 3550'55.34" E), at approximately 1650 m altitude in June 2012.

- Flowering tops from Smyrnium olusatrum were collected from a natural stand in Zekrit, Metn, along the Nahr al-Kalb River (3357'12.74" N 35³6'13.07" E), at approximately $50 \mathrm{~m}$ altitude in March 2012.

Plants have been collected according to the national biodiversity rights of Lebanon. Voucher specimens were deposited at the Herbarium of the Department of Botany and Medicinal plants, Holy Spirit University, Faculty of Agricultural and Food Sciences (USEK- 
Lebanon), under the registry numbers MNU598, MNU640b, MNU618 and MNU615 respectively.

\subsection{Essential oil extraction:}

The essential oils (EOs) were obtained by hydrodistillation performed for $3 \mathrm{~h}$ using a Clevenger-type apparatus according to the European Pharmacopoeia (15). The D. carota flowers yielded $0.23 \%$ EO (253.9 g of plant material were used to obtain $0.6 \mathrm{ml}$ of EO), the

F. elaeochytris fruits yielded $0.86 \%$ EO (266.6 g of plant material were used to obtain $2.3 \mathrm{ml}$ of EO), the $P$. asperula fruits yielded $0.52 \% \mathrm{EO}$ (341 $\mathrm{g}$ of plant material were used to obtain $1.8 \mathrm{ml}$ of EO) and the $S$. olusatrum flowering tops yielded $0.12 \% \mathrm{EO}(457.8 \mathrm{~g}$ of plant material were used to obtain $0.7 \mathrm{ml}$ of EO).

\subsection{Essential oils analyses:}

\subsubsection{GC analyses}

Analytical gas chromatography was carried out on a Thermo Electron Corporation gas chromatograph fitted with a DB-5 MS capillary column $(30 \mathrm{~m} \times 0.25 \mathrm{~mm})$ with $0.1 \mu \mathrm{m}$ film thickness or a fused silica HP Innowax polyethylene glycol capillary column $(50 \mathrm{~m} \times 0.20$ $\mathrm{mm}$, film thickness $0.20 \mu \mathrm{m})$. Helium was the carrier gas $(0.7 \mathrm{ml} /$ minute $)$. The column temperature was initially set to $35^{\circ} \mathrm{C}$ before being gradually increased to $85^{\circ} \mathrm{C}$ at $5^{\circ} \mathrm{C} /$ minute, held for 20 minutes at $85^{\circ} \mathrm{C}$, raised to $300^{\circ} \mathrm{C}$ at $10^{\circ} \mathrm{C} / \mathrm{min}$ and finally held for 5 minutes at $300^{\circ} \mathrm{C}$. Diluted $1 \mu \mathrm{l}$ samples $(1 / 100, \mathrm{v} / \mathrm{v})$ were injected at $250^{\circ} \mathrm{C}$ manually and in the splitless mode. Flame ionisation detection (FID) was performed at $310^{\circ} \mathrm{C}$.

\subsubsection{GC/MS analyses}

The GC/MS analyses were performed using an Agilent gas chromatograph 6890 coupled with Mass Detector 5975. The 7683 B auto sampler injected $1 \mu \mathrm{L}$ of each oil sample. A fused silica capillary column DB-5 MS (30 $\mathrm{m} \times 0.25 \mathrm{~mm}$ internal diameter, film thickener $0.1 \mu \mathrm{m})$ 
or a fused silica HP Innowax polyethylene glycol capillary column $(50 \mathrm{~m} \times 0.20 \mathrm{~mm}$, film thickness $0.20 \mu \mathrm{m})$ was used. Helium was the carrier gas $(0.7 \mathrm{ml} /$ minute $)$. The oven temperature program was identical to that described in 2.3.1. The mass spectra were recorded at $70 \mathrm{eV}$ with an ion source temperature of $310^{\circ} \mathrm{C}$ and a transfer line heated to $320^{\circ} \mathrm{C}$. The acquisition was recorded in full scan mode $(50-400 \mathrm{amu})$.

\subsubsection{Identifications and quantifications}

Most constituents were identified by gas chromatography by comparing their retention indices (RI) with those from the literature $(16,17)$ or with those of authentic compounds obtained from Sigma-Aldrich (Lebanon). The retention indices were determined relative to a homologous series of $n$-alkanes (C8 to C24) analysed under the same operating conditions. Further identification was obtained by comparing their mass spectra on both columns with those provided in the NIST and Wiley 275 libraries, our home-made library constructed with pure compounds and EOs of known composition or with mass spectra from the literature (17, 18). The relative concentrations of the components were calculated based on the GC peak areas without correction (Figure 2); they are reported in Table 1.

2.3.4. Identification of the main furanosesquiterpenes of Smyrnium olusatrum L. EO by NMR spectroscopy

The nuclear magnetic resonance (NMR) spectra $\left({ }^{1} \mathrm{H}-\mathrm{NMR},{ }^{13} \mathrm{C}-\mathrm{NMR},{ }^{1} \mathrm{H}-{ }^{1} \mathrm{H}\right.$ COSY, HSQC and HMBC) of crude Smyrnium olusatrum L. EO allowed us to confirm the identification of the main constituents (furanodiene and furanoeremophil-1-one (Figure 1)) by comparison with the NMR data reported in the literature $(19,20)$.

The NMR spectra were recorded on a Bruker $500 \mathrm{MHz}$ spectrometer equipped with a $1 \mathrm{~mm}$ inverse detection probe.

The characteristic signals are as follows: 
Furanodiene (11): ${ }^{1} \mathrm{H}$ NMR (500 MHz, $\left.\mathrm{CDCl}_{3}\right): \delta(\mathrm{ppm}) 1.27(3 \mathrm{H}, \mathrm{s}, \mathrm{H}-15), 1.62(3 \mathrm{H}$, m, H-14), 1.93 (3H, d, $J=1.2 \mathrm{~Hz}, \mathrm{H}-13), 3.43$ (2H, d, $J=15.9 \mathrm{~Hz}, \mathrm{H}-9 \mathrm{a}), 3.49$ (2H, d, $J=$ $15.9 \mathrm{~Hz}, \mathrm{H}-9 \mathrm{~b}), 4.76$ (1H, br d, $J=10.2 \mathrm{~Hz}, \mathrm{H}-5), 4.99$ (1H, m, H-1), 7.15 (1H, m, H-12). ${ }^{13} \mathrm{C}-$ NMR (500 MHz, $\left.\mathrm{CDCl}_{3}\right): \delta(\mathrm{ppm}) 9.0$ (C-13), 16.4 (C-15), 16.6 (C-14), 41.5 (C-9), 128.5 (C5), 129.5 (C-4), 130.0 (C-1), 134.9 (C-10), 137 (C-12).

Furanoeremophil-1-one (12): ${ }^{1} \mathrm{H}-\mathrm{NMR}\left(500 \mathrm{MHz}, \mathrm{CDCl}_{3}\right): \delta(\mathrm{ppm}) 0.62(3 \mathrm{H}, \mathrm{s}, \mathrm{H}-$ 14), $1.06(3 \mathrm{H}, \mathrm{d}, J=6.7 \mathrm{~Hz}, \mathrm{H}-15), 1.92(3 \mathrm{H}, \mathrm{d}, J=1.2 \mathrm{~Hz}, \mathrm{H}-13), 2.05(1 \mathrm{H}, \mathrm{dd}, J=6.7$ and $3.7 \mathrm{~Hz}, \mathrm{H}-4), 2.68$ (1H, s, H-10), 7.15 (1H, m, H-12). ${ }^{13} \mathrm{C}-\mathrm{NMR}\left(500 \mathrm{MHz}, \mathrm{CDCl}_{3}\right): \delta$ (ppm) 8.2 (C-13), 12.2 (C-14), 15.2 (C-15), 42.0 (C-5), 42.7 (C-4), 54.5 (C-10), 137.0 (C-12), 209.5 $(\mathrm{C}-1)$.

\subsection{Antimicrobial activity:}

\subsubsection{Microorganisms}

The antimicrobial activity of the essential oils was investigated against Gram (-) bacterial strain Escherichia coli ATCC 25922; Gram (+) bacterial strain Staphylococcus aureus ATCC 29213; yeasts Candida albicans ATCC 10231, Candida parapsilosis ATCC 22019 and Cryptococcus neoformans SNB-CN1; filamentous fungi Trichophyton rubrum SNB-TR1, Trichophyton violaceum SNB-TV1, Trichophyton soudanense SNB-TS1, Trichophyton tonsurans SNB-TT1, Trichophyton mentagrophytes SNB-TM1 and Aspergillus fumigatus SNB-AF1. The ATCC strains were purchased, while the others were clinical isolates kindly provided by Prof. Philippe Loiseau, Université Paris Sud. These strains were identified by Prof. Philippe Loiseau and Christian Bories; the molecular analyses were conducted by BACTUP. The ITS sequences were deposited in the NCBI GenBank database under the following registry numbers: KF360235 (C. neoformans SNB-CN1), KC692746 (T. rubrum SNB-TR1), KF360236 (T. violaceum SNB-TV1), KF360237 (T. soudanense SNB-TS1), 
KF360238 (T. tonsurans SNB-TT1), KF360239 (T. mentagrophytes SNB-TM1) and KC692747 (A. fumigatus SNB-AF1).

\subsubsection{Microdilution method}

The broth microdilution method was used to determine the minimal inhibitory concentration (MIC) of the EOs according to the Clinical and Laboratory Standards Institute guidelines (21, $22,23,24)$. The investigated essential oils were diluted in DMSO and tested at concentrations ranging from 512 to $1 \mu \mathrm{g} / \mathrm{ml}$. Oxacillin and gentamicin $(16-0.03 \mu \mathrm{g} / \mathrm{ml})$ were used as reference antibiotics, while itraconazole $(16-0.03 \mu \mathrm{g} / \mathrm{ml})$ and fluconazole $(64-0.125 \mu \mathrm{g} / \mathrm{ml})$ were used as positive controls for antifungal activity. These antimicrobial standards drugs were purchased from Molekula. The microplates were incubated at $37^{\circ} \mathrm{C}$ for $24 \mathrm{~h}$ for bacteria, $48 \mathrm{~h}$ for fungi and yeasts and five days for dermatophytes. The MIC values referring to the lowest concentration preventing visible microbial growth are reported in Table 2.

\section{Results and discussion:}

\subsection{Essential oils analyses:}

The chemical compositions of the four Apiaceae essential oils are reported in Table 1; the relative proportions of the components are given. The yields of essential oils obtained by hydrodistillation ranged from $0.12 \%$ to $0.86 \%$, in S. olusatrum flowering tops and $F$. elaeochytris fruits, respectively.

The oils of $F$. elaeochytris and $P$. asperula were essentially composed of monoterpene hydrocarbons ( $80.2 \%$ and $74.4 \%)$. The two main constituents of the F. elaeochytris fruit oil were $\alpha$-pinene ( $71.8 \%$ ) and $\beta$-pinene ( $6.80 \%$ ), representing $78.6 \%$ of the total oil . The $P$. asperula fruit EO was more complex with five components above 5\%: sabinene ( $29.8 \%$ ), $\beta$ -

phellandrene ( $19.2 \%$ ), $\alpha$-pinene ( $9.8 \%$ ), trans-nerolidol ( $9.2 \%$ ) and $\alpha$-phellandrene ( 8.0 $\%)$. The D. carota flower EO was rich in monoterpene hydrocarbons $(40.2 \%)$ and 
oxygenated sesquiterpenes $(26.9 \%)$. The main constituents were $\alpha$-pinene ( $27.4 \%$ ), carotol ( $26.3 \%$ ), $\alpha$-humulene ( $9.8 \%$ ), germacrene D ( $7.0 \%$ ) and myrcene ( $5.3 \%$ ). Finally, the $S$. olusatrum flowering tops EO was characterised by the dominance of furanosesquiterpenoids, accounting for $77.3 \%$ of the total volatile oil (Figure 1). Furanodiene (1) and its Cope rearrangement product curzerene (2) (together $44.6 \%)$ and furanoeremophil-1-one (3, 28.5 \%) were the most abundant compounds in the GC profile. Curzerene can be produced from furanodiene through a thermal Cope rearrangement due to the high temperatures in the injection insert during gas chromatographic analysis $(25,26)$.

1D and 2D NMR analyses were performed on the crude oil to differentiate these two isomers; curzerene could not be detected, while its precursor (furanodiene, 1) was the major component. Therefore, the GC peak attributed to cuzerene should be treated as a second peak for furanodiene (1), accounting for $44.6 \%$ of the EO. NMR also confirmed the identification of the second major compound: furanoeremophil-1-one (3).

\section{(Table 1)}

(Figure 1)

The Lebanese EOs of the four studied Apiaceae species showed some differences in their chemical composition compared to those previously reported in the literature. Although $D$. carota $\mathrm{EO}$ has been the subject of several studies, the subspecies maximus remains poorly explored. A previous study reported the oil composition of D. carota subsp. maximus growing in Portugal and showed a markedly different composition compared to the Lebanese EO reported in our study (Valente). The Portuguese EO being mainly composed of $\alpha$-pinene, geranyl acetate, $\beta$-bisabolene, $\alpha$-asarone and E- methylisoeugenol doesn't share any major compound with the Lebanese EO, except for the $\alpha$-pinene. However, high relative proportion of carotol, one of the main components of the Lebanese D. carota oil, has been reported in $D$. carota seeds cultivated in Turkey (Özcan and Chalchat). As for F. elaeochytris, few reports 
are available on the chemistry and bioactivity of the oil given the limited geographical distribution of the species. One of the rare studies reported in turkey showed a considerably lower relative proportion of $\alpha$-pinene and $\beta$-pinene (Baser et al). The chemical composition of the P. asperula EO has been mainly studied in Iran (Refs Iran). Compared to the Lebanese EO, several differences can be pointed out, in particular, the absence of sabine, $\alpha-$ phellandrene and nerolidol in these oils. And finally, all previous reports indicate that $S$. olusatrum EO is a rich source of furanosesquiterpenes with high relative proportions of curzerene (refs). Likewise, furanoeremophil-1-one, one of the main constituents of the Lebanese EO, has also been also reported as a major compound in Greece by Papaioannou et al. (ref). However, some differences are worth mentioning, like the absence of germacrone in our EO that is present in high relative proportion in some $S$. olusatrum oils (ref Greece; and Italy and Portugal).

\subsection{Antimicrobial activity:}

The minimum inhibitory concentrations (MICs) of the four Apiaceae essential oils are presented in Table 2. An oil was considered active if the minimal inhibitory concentration was $128 \mu \mathrm{g} / \mathrm{ml}$ or below (27). The different pathogens were diversely sensitive to the EOs.

Overall, the yeasts, Gram (-) bacterium E. coli and clinical isolates of the filamentous fungus A. fumigatus were resistant. However, the growth of Gram (+) bacterium S. aureus and the dermatophytic Trichophyton species was significantly inhibited. The most active inhibitors were the D. carota flowers and the $S$. olusatrum flowering tops oils. Notably, D. carota EO was only four times less active than oxacillin towards $S$. aureus with a MIC value of $8 \mu \mathrm{g} / \mathrm{ml}$. The significant antimicrobial effect of D. carota EO could be due to carotol, which is one of the major components of this oil. Carotol is known be involved in allelopathic interactions; it possesses antifungal, herbicidal and insecticidal potential (28). The antifungal activity of $D$. carota $\mathrm{EO}$ has been previously reported by Valente et al. and it was shown to be particularly 
active against dermatophytic fungi and Cryptococcus neoformans (Valente et al.). The $S$. olusatrum EO was very active against dermatophytes with MIC values of 32-64 $\mu \mathrm{g} / \mathrm{ml}$, suggesting a potential antifungal property for the furanosesquiterpernes present in the oil. These results highlight the antifungal potential of this EO and are in full agreement with Marongiu et al. who also reported an antifungal activity of $S$. olusatrum EO against dermatophytic fungi (Marongiu et al.), thus, encouraging its use against dermatophytoses.

D. carota, F. elaeochytris, S. olusatrum and $P$. asperula are used in the traditional herbal medicine and are listed in the Lebanese pharmacopoeia. They are employed for wound disinfection and to cure several ailments, including microbial infections $(9,10,11)$. Our results showed that the EOs from these plants possess antibacterial and antifungal potential and corroborate their traditional medical usage.

(Table 2)

\section{Conclusion:}

The present study demonstrated the effective antimicrobial activity of the EOs from the Apiaceae family, particularly against $S$. aureus and dermatophytic fungi. The antibacterial and antifungal potential observed may justify the use of these plants in herbal medicine as antimicrobial agents. In addition, this study highlighted the interesting antimicrobial potential of the EOs of D. carota rich in carotol and S. olusatrum mainly composed of furanosesquiterpenes (furanodiene and furanoeremophil-1-one). It is reasonable to hypothesize that these natural products are antimicrobial and could be used in the bio-inspired reconstruction of antimicrobial mixtures. Nevertheless, further studies are required to understand the mechanism of action and to obtain more information regarding the safety and toxicity of the oils and their constituents.

\section{Funding}


This work has benefited from an "Investissement d'Avenir" grant managed by Agence Nationale de la Recherche [CEBA, ref. ANR-10-LABX-25-01].

\section{References}

1. M.A. Pfaller and D.J. Diekema, Epidemiology of invasive candidiasis: a persistent public health problem. Clinical Microbiology Reviews, 20, 133-163 (2007).

2. M. Nucci and K.A. Marr, Emerging fungal diseases. Clinical Infectious Diseases, 41, $521-526$ (2005).

3. R. Smith and J. Coast, The true cost of antimicrobial resistance. British Medical Journal, 346, f1493 (2013).

4. A.E. Edris, Pharmaceutical and therapeutic Potentials of essential oils and their individual volatile constituents: a review. Phytotherapy Research, 21, 308-323 (2007).

5. D. Kalemba and A. Kunicka, Antibacterial and antifungal properties of essential oils. Current Medical Chemistry, 10, 813-829 (2003).

6. H.A.E. Shaaban, A.H. El-Ghorab and T. Shibamoto, Bioactivity of essential oils and their volatile aroma components: Review. Journal Of Essential Oil Research, 24, 203$212(2012)$.

7. M.G. Pimenov and M.V. Leonov, The Asian Umbelliferae biodiversity database (ASIUM) with particular reference to south-west Asian taxa. Turkish Journal of Botany, 28, 139-145 (2004).

8. R. Hegnauer, Chemical Patterns and Relationships of Umbelliferae. In: The biology and chemistry of the Umbelliferae. V.H. Heywood edn., Academic Press, London (1971).

9. M. El Beyrouthy, Contribution à l'ethnopharmacologie libanaise et aux Lamiaceae du Liban. Ph.D. Thesis, Université de Lille 2 (2008). 
10. M. El Beyrouthy, N. Arnold, A. Delelis-Dusollier and F. Dupont, Plants used as remedies antirheumatic and antineuralgic in the traditional medicine of Lebanon. Journal of Ethnopharmacology, 120, 315-334 (2008).

11. M. El Beyrouthy, Contribution à l'ethnopharmacologie libanaise et aux Lamiaceae du Liban, Résumé de thèse. Acta Botanica Gallica, 156, 515-521 (2009).

12. Euro-Mediterranean plant diversity (Euro+Med) Website. http://ww2.bgbm.org/EuroPlusMed/ (25 August 2016)

13. P. Mouterde, Nouvelle flore du Liban et de la Syrie, pp. 640, Distribution Librairie Orientale Beyrouth, Liban (1983).

14. P. Mouterde Nouvelle flore du Liban et de la Syrie, pp. 618, Distribution Librairie Orientale Beyrouth, Liban (1983).

15. European Pharmacopoeia, Council of Europe Publishing, $3^{\text {rd }}$ edn., Strasbourg (1997).

16. N.W. Davies, Gas chromatographic retention indices of monoterpenes and sesquiterpenes on methyl silicone and carbowax 20M phases. Journal of Chromatography A, 503, 1-24 (1990).

17. W. Jennings and T. Shibamoto, Qualitative analysis of flavour and fragrance volatiles by glass capillary gas chromatography. Academic Press, New York (1980).

18. R.P. Adams, Identification of Essential Oil Components by Gas Chromatography/Mass Spectrometry, 4th edn. Allured Publ. Corp., Carol Stream, IL (2007).

19. A. Dekebo, E. Dagne and O. Sterner, Furanosesquiterpenes from Commiphora sphaerocarpa and related adulterants of true myrrh. Fitoterapia, 73, 48-55 (2002).

20. U. Mölleken, V. Sinnwell and K.H. Kubeczka, Essential oil composition of Smyrnium olusatrum. Phytochemistry, 49, 1709-1714 (1998). 
21. Clinical and Laboratory Standards Institute, Methods for dilution antimicrobial susceptibility tests for bacteria that grow aerobically, Approved Standard, $8^{\text {th }}$ edn. Document M7-A8, CLSI, Wayne, PA, USA (2009).

22. Clinical and Laboratory Standards Institute, Reference method for broth dilution antifungal susceptibility testing of filamentous fungi, Approved Standard, $2^{\text {nd }}$ edn. Document M38-A2, CLSI, Wayne, PA, USA (2008).

23. Clinical and Laboratory Standards Institute, Reference method for broth dilution antifungal susceptibility testing of yeasts, Approved Standard, $3^{\text {rd }}$ edn. Document M27-A3, CLSI, Wayne, PA, USA (2008).

24. A.M.S. Rodrigues, P.N.E.T. Theodoro, C. Basset, M.R.R. Silva, J. Beauchêne, L.S. Espindola and D. Stien, Search for Antifungal Compounds from the Wood of Durable Tropical Trees. Journal of Natural Products, 73, 1706-1707 (2010).

25. N. Baldovini, F. Tomi and J. Casanova, Identification and quantitative determination of furanodiene, a heat-sensitive compound, in essential oil by ${ }^{13} \mathrm{C}-\mathrm{NMR}$. Phytochemical Analysis, 12, 58-63 (2001).

26. F. Maggi, L. Barboni, F. Papa, G. Caprioli, M. Ricciutelli, G. Sagratini and S. Vittori, A forgotten vegetable (Smyrnium olusatrum L., Apiaceae) as a rich source of isofuranodiene. Food Chemistry, 135, 2852-2862 (2012).

27. P. Cos, A. Vlietinck and D. Vanden Berghe, Anti-infective potential of natural products: How to develop a stronger in vitro "proof-of-concept". Journal of Ethnopharmacology, 106, 290-302 (2006).

28. I. Jasicka-Misiak, J. Lipok, E.M. Nowakowska, P.P. Wieczorek, P. Młynarz and P. Kafarski, Antifungal activity of the carrot seed oil and its major sesquiterpene compounds. Zeitschrift Naturforschung C, 59, 791-796 (2004). 
Table 1. Composition of the essential oils of the four Apiaceae

\begin{tabular}{|c|c|c|c|c|c|c|c|c|}
\hline & & & & & $\begin{array}{c}\text { D. carota } \\
\text { subsp. maximus } \\
\text { Flowers EO }\end{array}$ & $\begin{array}{c}F . \\
\text { elaeochytris } \\
\text { Fruits EO }\end{array}$ & $\begin{array}{l}\text { P. asperula } \\
\text { Fruits EO }\end{array}$ & $\begin{array}{l}\text { S. olusatrum } \\
\text { Flowering tops } \\
\text { EO }\end{array}$ \\
\hline & $\mathrm{R}_{\mathrm{i}}^{\mathrm{a}}$ & $\mathrm{R}_{\mathrm{i}}^{\mathrm{b}}$ & Compound ID & Identification $^{\mathrm{c}}$ & & & & \\
\hline 1 & 938 & 1076 & $\alpha$-Pinene & $\mathrm{R}_{\mathrm{i}}, \mathrm{MS}, \mathrm{CoGC}$ & 27.4 & 71.8 & 9.8 & 1.2 \\
\hline 2 & 953 & 1076 & Camphene & $\mathrm{R}_{\mathrm{i}}$, MS, CoGC & 0.7 & 0.7 & 0.1 & $\mathrm{t}$ \\
\hline 3 & 973 & 1132 & Sabinene & $\mathrm{R}_{\mathrm{i}}, \mathrm{MS}, \mathrm{CoGC}$ & - & - & 29.8 & - \\
\hline 4 & 980 & 1118 & $\beta$-Pinene & $\mathrm{R}_{\mathrm{i}}$, MS, CoGC & 3.1 & 6.8 & - & 0.2 \\
\hline 5 & 993 & 1174 & Myrcene & $\mathrm{R}_{\mathrm{i}}$, MS, CoGC & 5.3 & 0.5 & 1.5 & 0.1 \\
\hline 6 & 1005 & 1188 & $\alpha$-Phellandrene & $\mathrm{R}_{\mathrm{i}}$, MS, CoGC & $\mathrm{t}$ & $\mathrm{t}$ & 8.0 & 0.1 \\
\hline 7 & 1013 & 1159 & $\delta$-3-Carene & $\mathrm{R}_{\mathrm{i}}, \mathrm{MS}$ & $\mathrm{t}$ & - & 1.7 & 0.2 \\
\hline 8 & 1025 & 1280 & $p$-Cymene & $\mathrm{R}_{\mathrm{i}}, \mathrm{MS}, \mathrm{CoGC}$ & 0.1 & $\mathrm{t}$ & - & 0.1 \\
\hline 9 & 1030 & 1203 & Limonene & $\mathrm{R}_{\mathrm{i}}$, MS, CoGC & 3.1 & 0.4 & - & - \\
\hline 10 & 1037 & 1218 & $\beta$-phellandrene & $\mathrm{R}_{\mathrm{i}}, \mathrm{MS}, \mathrm{CoGC}$ & - & - & 19.2 & 1.7 \\
\hline 11 & 1050 & 1253 & trans- $\beta$-ocimene & $\mathrm{R}_{\mathrm{i}}, \mathrm{MS}$ & 0.9 & $\mathrm{t}$ & 1.1 & 0.5 \\
\hline 12 & 1057 & 1255 & $\gamma$-Terpinene & $\mathrm{R}_{\mathrm{i}}$, MS, CoGC & 0.1 & $\mathrm{t}$ & 3.2 & 0.2 \\
\hline 13 & 1058 & 1556 & cis-sabinene hydrate & $\mathrm{R}_{\mathrm{i}}, \mathrm{MS}$ & - & - & $\mathrm{t}$ & - \\
\hline 14 & 1075 & - & m-Cresol & $\mathrm{R}_{\mathrm{i}}, \mathrm{MS}$ & - & - & 1.2 & - \\
\hline 15 & 1098 & 1553 & Linalool & $\mathrm{R}_{\mathrm{i}}, \mathrm{MS}, \mathrm{CoGC}$ & 0.1 & - & - & $\mathrm{t}$ \\
\hline 16 & 1140 & 1663 & cis-Verbenol & $\mathrm{R}_{\mathrm{i}}, \mathrm{MS}$ & - & 0.1 & - & - \\
\hline 17 & 1176 & 1611 & Terpinen-4-ol & $\mathrm{R}_{\mathrm{i}}, \mathrm{MS}$ & 0.1 & 0.1 & 2.9 & - \\
\hline 18 & 1182 & 1864 & p-Cymen-8-ol & $\mathrm{R}_{\mathrm{i}}, \mathrm{MS}$ & - & $\mathrm{t}$ & - & - \\
\hline 19 & 1196 & 1804 & Myrteneol & $\mathrm{R}_{\mathrm{i}}$, MS, CoGC & - & $\mathrm{t}$ & - & - \\
\hline 20 & 1217 & 1725 & Verbenone & $\mathrm{R}_{\mathrm{i}}, \mathrm{MS}$ & - & $\mathrm{t}$ & - & - \\
\hline 21 & 1217 & 1845 & trans-Carveol & $\mathrm{R}_{\mathrm{i}}, \mathrm{MS}$ & - & $\mathrm{t}$ & - & - \\
\hline 22 & 1215 & 1772 & Citronellol & $\mathrm{R}_{\mathrm{i}}, \mathrm{MS}$ & - & - & - & $\mathrm{t}$ \\
\hline 23 & 1284 & 1597 & Bornyl acetate & $\mathrm{R}_{\mathrm{i}}$, MS, CoGC & 0.1 & $\mathrm{t}$ & - & - \\
\hline 24 & 1227 & 1698 & Myrtenyl acetate & $\mathrm{R}_{\mathrm{i}}, \mathrm{MS}$ & - & $\mathrm{t}$ & - & - \\
\hline 25 & 1352 & 1466 & $\alpha$-Cubebene & $\mathrm{R}_{\mathrm{i}}, \mathrm{MS}$ & - & $\mathrm{t}$ & - & - \\
\hline 26 & 1377 & 1497 & $\alpha$-Copaene & $\mathrm{R}_{\mathrm{i}}, \mathrm{MS}$ & 0.2 & 0.1 & $\mathrm{t}$ & $\mathrm{t}$ \\
\hline 27 & 1378 & 1600 & $\beta$-Elemene & $\mathrm{R}_{\mathrm{i}}, \mathrm{MS}$ & 0.4 & 0.3 & $\mathrm{t}$ & 0.9 \\
\hline 28 & 1385 & 1535 & $\beta$-Bourbonene & $\mathrm{R}_{\mathrm{i}}, \mathrm{MS}$ & 0.1 & - & - & 0.1 \\
\hline 29 & 1415 & 1612 & $\beta$-Caryophyllene & $\mathrm{R}_{\mathrm{i}}$, MS, CoGC & 2.9 & - & $\mathrm{t}$ & 0.4 \\
\hline 30 & 1437 & 1628 & Aromadendrene & $\mathrm{R}_{\mathrm{i}}, \mathrm{MS}$ & - & 0.8 & $\mathrm{t}$ & 0.7 \\
\hline 31 & 1452 & 1668 & $\alpha$-Humulene & $\mathrm{R}_{\mathrm{i}}, \mathrm{MS}$ & 9.8 & $\mathrm{t}$ & - & 0.1 \\
\hline 32 & 1455 & 1689 & $\beta$-farnesene & $\mathrm{R}_{\mathrm{i}}, \mathrm{MS}$ & 1.2 & 0.4 & 0.3 & - \\
\hline 33 & 1463 & 1661 & allo-Aromadendrene & $\mathrm{R}_{\mathrm{i}}, \mathrm{MS}$ & - & - & - & $\mathrm{t}$ \\
\hline 34 & 1477 & 1726 & D-Germacrene & $\mathrm{R}_{\mathrm{i}}, \mathrm{MS}$ & 7.0 & 0.7 & 0.3 & 2.9 \\
\hline 35 & 1496 & 1743 & Curzerene $^{d}$ & $\mathrm{R}_{\mathrm{i}}, \mathrm{MS}$ & - & - & - & 31.5 \\
\hline 36 & 1498 & 1744 & $\alpha$-Selinene & $\mathrm{R}_{\mathrm{i}}, \mathrm{MS}$ & 0.7 & - & 0.3 & - \\
\hline 37 & 1505 & 1758 & $\alpha$-Farnesene & $\mathrm{R}_{\mathrm{i}}, \mathrm{MS}$ & 0.1 & - & - & - \\
\hline 38 & 1508 & 1741 & $\beta$-Bisabolene & $\mathrm{R}_{\mathrm{i}}, \mathrm{MS}$ & 0.4 & - & 0.2 & - \\
\hline 39 & 1510 & 1778 & $\alpha$-Bisabolene & $\mathrm{R}_{\mathrm{i}}, \mathrm{MS}$ & - & 3.6 & 0.4 & - \\
\hline 40 & 1526 & 1773 & $\delta$-Cadinene & $\mathrm{R}_{\mathrm{i}}, \mathrm{MS}$ & 0.3 & 0.7 & 0.4 & 0.2 \\
\hline 41 & 1566 & 2050 & Nerolidol & $\mathrm{R}_{\mathrm{i}}, \mathrm{MS}$ & - & - & 9.2 & - \\
\hline 42 & 1577 & 2008 & Caryophyllene oxide & $\mathrm{R}_{\mathrm{i}}, \mathrm{MS}, \mathrm{CoGC}$ & 0.2 & - & - & - \\
\hline 43 & 1580 & 2152 & Spathulenol & $\mathrm{R}_{\mathrm{i}}, \mathrm{MS}, \mathrm{CoGC}$ & - & 0.2 & - & - \\
\hline 44 & 1593 & 2082 & $\beta$-elemenone & $\mathrm{R}_{\mathrm{i}}, \mathrm{MS}$ & - & - & - & 3.2 \\
\hline 45 & 1595 & 2033 & Carotol & $\mathrm{R}_{\mathrm{i}}, \mathrm{MS}$ & 26.3 & - & - & - \\
\hline 46 & 1640 & 2188 & T-cadinol & $\mathrm{R}_{\mathrm{i}}, \mathrm{MS}$ & - & - & 0.4 & - \\
\hline 47 & 1643 & 2256 & $\alpha$-cadinol & $\mathrm{R}_{\mathrm{i}}, \mathrm{MS}$ & - & - & 1.8 & - \\
\hline 48 & 1688 & 2229 & $\alpha$-Bisabolol & $\mathrm{R}_{\mathrm{i}}, \mathrm{MS}, \mathrm{CoGC}$ & 0.4 & 4.3 & 3.1 & 2.5 \\
\hline 49 & 1694 & - & Furanodiene $^{\mathrm{d}}$ & NMR & - & - & - & 13.1 \\
\hline 50 & 1704 & 2649 & Furano-4(15)-eudesmen-1-one & $\mathrm{R}_{\mathrm{i}}, \mathrm{MS}$ & - & - & - & 4.2 \\
\hline 51 & 1875 & 2706 & Furanoeremophil-1-one & NMR & - & - & - & 28.5 \\
\hline 52 & 1950 & 2614 & Phytol & $\mathrm{R}_{\mathrm{i}}, \mathrm{MS}$ & 0.1 & - & - & - \\
\hline \multirow[t]{8}{*}{53} & 1957 & 2993 & Hexadecanoic acid & $\mathrm{R}_{\mathrm{i}}, \mathrm{MS}$ & 0.1 & - & 0.2 & - \\
\hline & & & Monoterpene hydrocarbons & & 40.2 & 80.2 & 74.4 & 4.3 \\
\hline & & & Oxygenated monoterpenes & & 0.2 & 0.2 & 4.1 & - \\
\hline & & & Sesquiterpene hydrocarbons & & 23.1 & 6.6 & 1.9 & 5.3 \\
\hline & & & Oxygenated sesquiterpenes & & 26.9 & 4.5 & 14.5 & 5.7 \\
\hline & & & Furanosesquiterpenes & & - & - & - & 77.3 \\
\hline & & & Other compounds & & 0.3 & - & 0.2 & 0 \\
\hline & & & Total identified & & 90.7 & 91.5 & 95.1 & 92.6 \\
\hline
\end{tabular}

Notes: Bold numbers indicate the percentages higher than $2 \%$ to show main components; $\mathrm{t}=$ trace, less than 0.05 .

${ }^{\mathrm{a}}$ Retention index on a HP-5MS column

${ }^{\mathrm{b}}$ Retention index on an Innovax column. 
${ }^{\mathrm{c}}$ Ri Retention index identical to bibliography; MS: identification based on comparison of mass spectra. Co-GC: retention time identical to authentic compounds; NMR: comparison of NMR spectra with those reported in the literature.

${ }^{\mathrm{d}}$ Quantitative data are affected by thermal degradation. 
Table 2. Antimicrobial activities (MIC in $\mu \mathrm{g} / \mathrm{ml}$ ) of the essential oils

\begin{tabular}{|c|c|c|c|c|c|c|c|c|c|}
\hline Pathogens & EO & 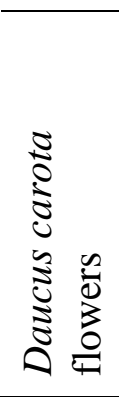 & 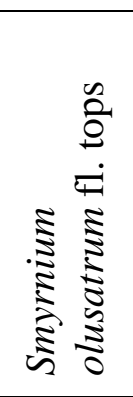 & 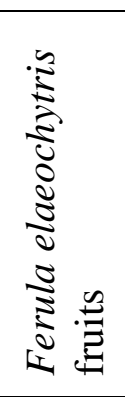 & 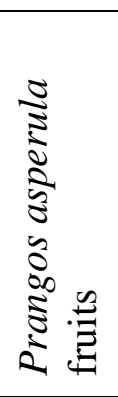 & 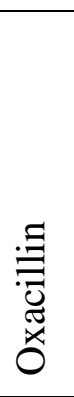 & 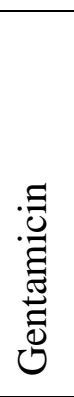 & 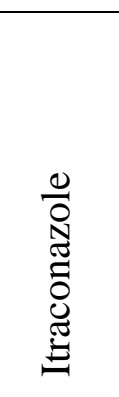 & 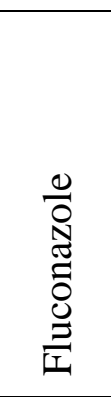 \\
\hline \multirow[t]{2}{*}{ Bacteria $^{a}$} & S.a. ATCC 29213 & 8 & 32 & 32 & 128 & 2 & - & - & - \\
\hline & E.c. АТCC 25922 & $>512$ & $>512$ & $>512$ & $>512$ & - & 8 & - & - \\
\hline \multirow[t]{3}{*}{ Yeasts ${ }^{b}$} & c.a. АТCC 10231 & 512 & 512 & 512 & 512 & - & - & 4 & 16 \\
\hline & C.p. АТСС 22019 & $>512$ & $>512$ & $>512$ & 512 & - & - & 0.5 & 2 \\
\hline & C.n. SNB-CN1 & 128 & 128 & 128 & 256 & - & - & 1 & 8 \\
\hline \multirow{6}{*}{$\begin{array}{l}\text { Filamentous } \\
\text { fungic }^{c}\end{array}$} & A.f. SNB-AF1 & $>512$ & $>512$ & $>512$ & $>512$ & - & - & 0.5 & $>512$ \\
\hline & T.r. SNB-TR1 & 32 & 64 & 128 & 64 & - & - & 0.03 & 2 \\
\hline & T.v. SNB-TV1 & 256 & 64 & 256 & 256 & - & - & 0.03 & 4 \\
\hline & T.s. SNB-TS1 & 64 & 32 & 128 & 128 & - & - & 0.03 & 4 \\
\hline & T.t. SNB-TT1 & 64 & 32 & 128 & 64 & - & - & 0.25 & 16 \\
\hline & T.m. SNB-TM1 & 32 & 32 & 64 & 128 & - & - & 0.125 & 64 \\
\hline
\end{tabular}

\footnotetext{
$\bar{a}$ S.a. $=$ Staphylococcus aureus, E.c. $=$ Echerichia coli,${ }^{b}$ C.a. $=$ Candida albicans, C.p. $=$ Candida parapsilosis, C.n. $=$ Cryptococcus neoformans,${ }^{c}$ A.f. $=$ Aspergillus fumigatus, T.r. $=$ Trichophyton rubrum, $T . v .=$ Trichophyton violaceum, T.s. $=$ Trichophyton soudanense, T.t. $=$ Trichophyton tonsurans, T.m. $=$ Trichophyton mentagrophytes.
} 
<smiles></smiles>

Furanodiene (11)<smiles>C=CC1Cc2c(C)coc2CC1C(C)C</smiles>

Curzerene (12)<smiles>Cc1coc2c1CC1(C)C(C)CCC(=O)C1C2</smiles>

Furanoeremophil-1-one (13)

Figure 1. GC chromatograms of the four Apiaceae Eos with peak identification of the major compounds as listed in table 1.

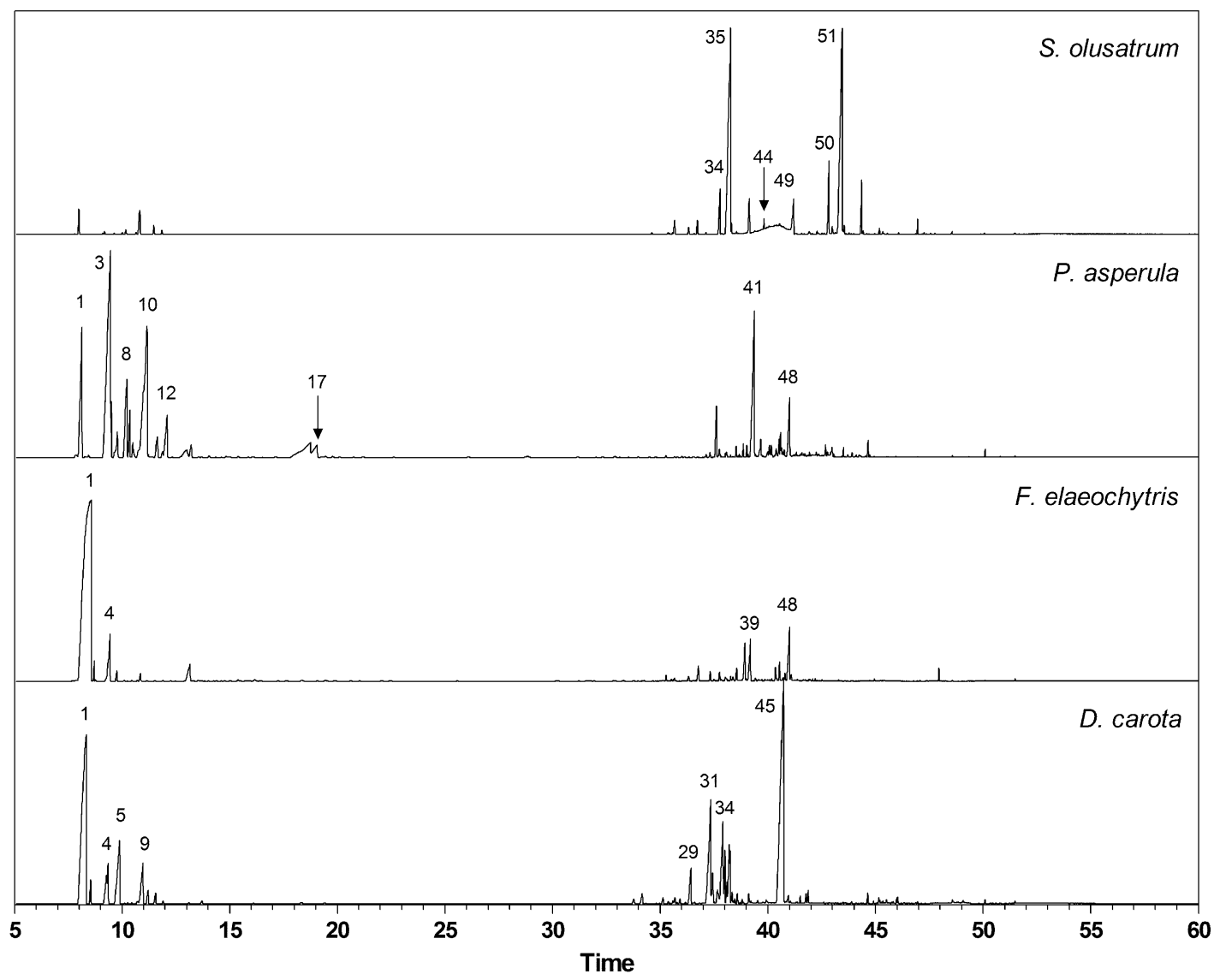

Figure 2. GC chromatograms of the four Apiaceae EOs with peak identification of the major compounds as listed in table 1. 